\title{
ACCUMULATION AND ICE-CORE STUDIES ON FILCHNER-RONNE ICE SHELF, ANTARCTICA
}

by

\author{
W. Graf*, H. Moser ${ }^{* *}$, H. Oerter ${ }^{* *}$, O. Reinwarth * and W. Stichler ** \\ $\left({ }^{*}\right.$ Kommission für Glaziologie der Bayerischen Akademie der Wissenschaften, \\ Marstallplatz 8, D-8000 München 22, Federal Republic of Germany)
}

(** Gesellschaft für Strahlen- und Umweltforschung mbH München (GSF), Institut für Hydrologie, Ingolstädter Landstraße 1, D-8042 Neuherberg, Federal Republic of Germany)

\section{ABSTRACT}

Accumulation rates in the eastern part of Ronne Ice Shelf were determined by isotopic stratigraphy $\left({ }^{18} \mathrm{O}\right)$. The samples were taken from snow-pits dug during the Filchner I and II operations in 1984 and 1986. In general, the accumulation rate decreases towards the south; the greatest decrease, from 21.3 to $13.3 \mathrm{~g} \mathrm{~cm}^{-2} \mathrm{a}^{-1}$, was observed between Filchner Station and measuring point 341 , sited $270 \mathrm{~km}$ up-stream of the ice edge. The $\delta^{18} \mathrm{O}$ values of the near-surface layers vary between -25 and $-29 \%$. The ${ }^{18} \mathrm{O}$ content in the more southerly part is progressively depleted in the direction of Möllereisstrom, paralleling a decrease in the accumulation rate. Near the ice edge the ${ }^{18} \mathrm{O}$ content decreases to the west. A $100 \mathrm{~m}$ ice core drilled in 1984 at point $340,220 \mathrm{~km}$ from the ice edge, probably goes back to A.D. 1460; it has been dated by isotopic stratigraphy.

The accumulation rate up-stream of the drilling site was deduced from the sequence of annual layers, using a simple ice-flow model. The accumulation shows strong variations over the last 200 years, which may be caused in part by local variations in the accumulation on Ronne Ice Shelf.

\section{INTRODUCTION}

The glaciological component of the German Antarctic research programme comprises:

(a) determination of annual snow-accumulation rates. Such data are indispensable for all investigations related to mass-balance studies;

(b) investigation of the particle paths through an ice shelf, in connection with the annual layering known from ice-core studies;

(c) investigation of the functional relation between the isotope content $\left({ }^{18} \mathrm{O} /{ }^{16} \mathrm{O},{ }^{2} \mathrm{H} /{ }^{1} \mathrm{H},{ }^{3} \mathrm{H} /{ }^{1} \mathrm{H}\right)$ of accumulated snow and ice, and the climatic environment.

Areas under investigation for this project are Ekström Ice Shelf, where the permanent German Antarctic research station Georg von Neumayer is located, and Filchner-Ronne Ice Shelf. Sampling started in the summer season 1979-80 during the German pre-site survey (Reinwarth 1981) and has continued since then. Preliminary results of the earlier investigations have been published by Reinwarth and others (1982, 1985). During the $1983-84$ and 1985-86 field seasons, extended glaciological investigations were carried out on Filchner-Ronne Ice Shelf, comprising snow-pit studies and ice-core drilling $220 \mathrm{~km}$ from the ice edge. The study of the first $90 \mathrm{~m}$ of the $100 \mathrm{~m}$ ice core from point 340 (cf. Fig. 1) has been described by Graf and others (1988).

\section{SAMPLING}

Figure 1 shows the area under investigation. The points at which snow samples were taken are indicated. Sampling points 140, 141, 240, 241, 340, and 341 are measuring sites of the Filchner I traverse in 1983-84 (Reinwarth and others 1984). During the Filchner II operation in 1985-86 samples were taken again at points $240,241,340$, and 341 . The new points $335,330,231,230$, and 131 are located in the more central part of Ronne Ice Shelf, and point 345 lies east of the first traverse. Sampling during 1985-86 was carried out by the Institute of Environmental Physics at the University of Heidelberg. Point 340 was the drilling site for the ice core described in section 4. The Filchner III operation (planned for 1986-87), which was to comprise new drilling and snow-pit studies at locations south of point 341 , had to be abandoned, so that no information is available on accumulation, flow velocity, and strain-rates in this part of Ronne Ice Shelf. Such data would not only be very helpful for completing the maps of accumulation rates and ${ }^{18} \mathrm{O}$ content, but also for the interpretation of the ice-core results.

\section{SNOW-PIT STUDIES}

\subsection{Isotope content}

Samples for ${ }^{18} \mathrm{O}$ analysis were collected at $5 \mathrm{~cm}$ intervals from the walls of snow-pits, so that on average each annual layer is represented by $8-10$ samples. Figure 2 is a compilation of all the profiles of the ${ }^{18} \mathrm{O}$ content of locations at which snow samples were taken in 1984 and 1986. At sites where samples were taken twice, i.e. in 1984 and 1986, we have a record through six summer seasons which dates back to 1979; at the other sites, between 2 and 5 years' accumulation are detectable.

All isotope profiles allow clear recognition of the annual layers, which can then be used to determine annual accumulation rates (see section 3.2). The decrease in ${ }^{18} \mathrm{O}$ content after the summer maximum at the beginning of the new winter season has been used to indicate the limits of the accumulation for 1 year.

The annual means of the $\delta^{18} \mathrm{O}$ values range between $-24.6 \pm 0.8 \%$ at point 140 (see Reinwarth and others 1985) and $-29.6 \pm 1.6 \%$ at point 345 . The 1983 layer was sampled twice (during 1984 and 1986) at points 240, 241, and 341 . The ${ }^{18} \mathrm{O}$ content varies only within the measuring accuracy, whereas amounts of accumulation differ by 10 , 12 , or $20 \%$ respectively (cf. Fig. 4 ), as will be shown below. This signifies that the isotope content will not be affected by the structure of the snow surface as much as the amount of accumulation. The same effect had already been noticed (Reinwarth and others 1985) when snow-pits dug in different years at adjacent sites were compared.

The spatial distribution of the ${ }^{18} \mathrm{O}$ content can give an 


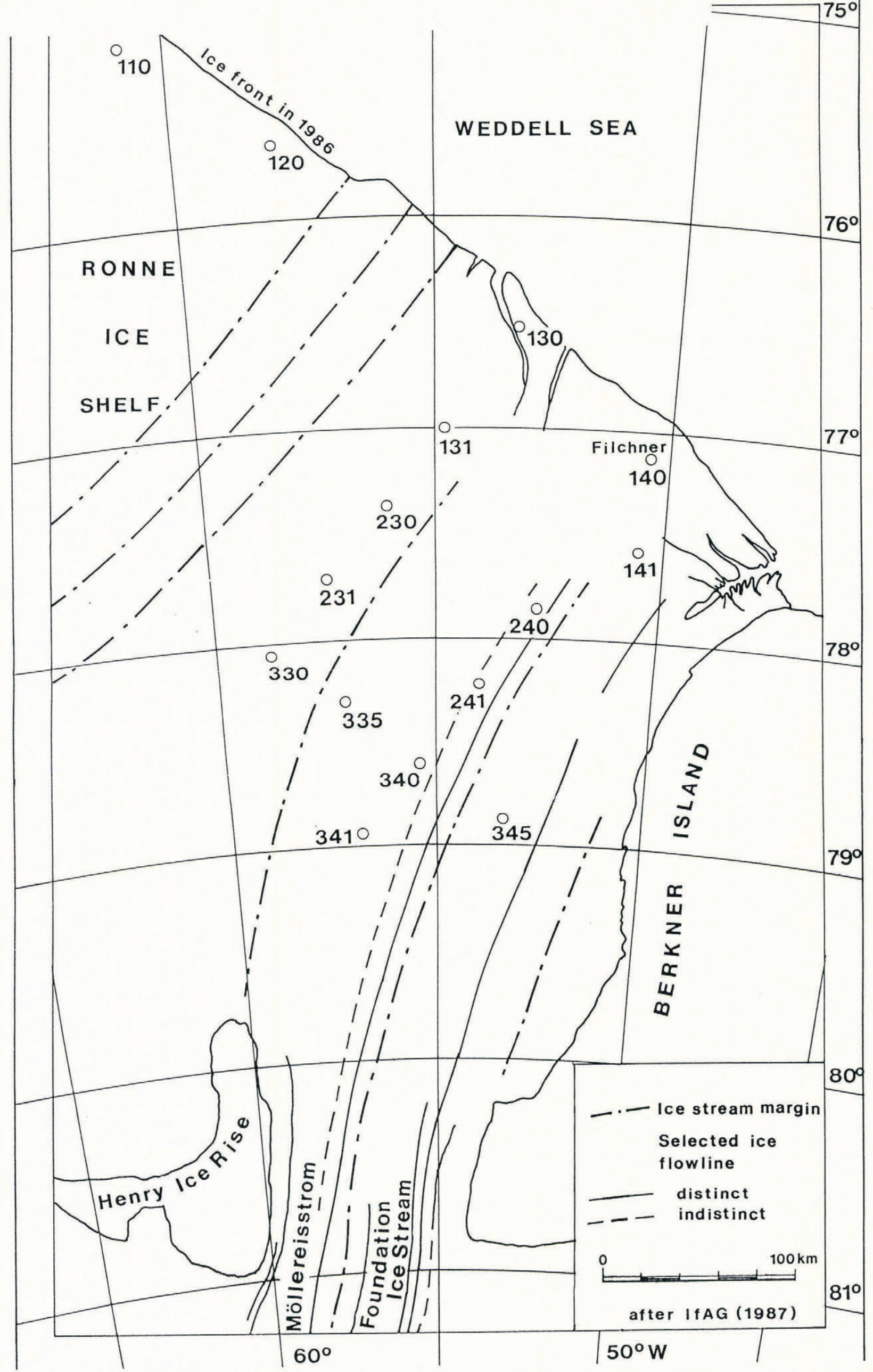

Fig. 1. Location of the sampling points on Filchner-Ronne Ice Shelf (after Swithinbank and others 1987). 

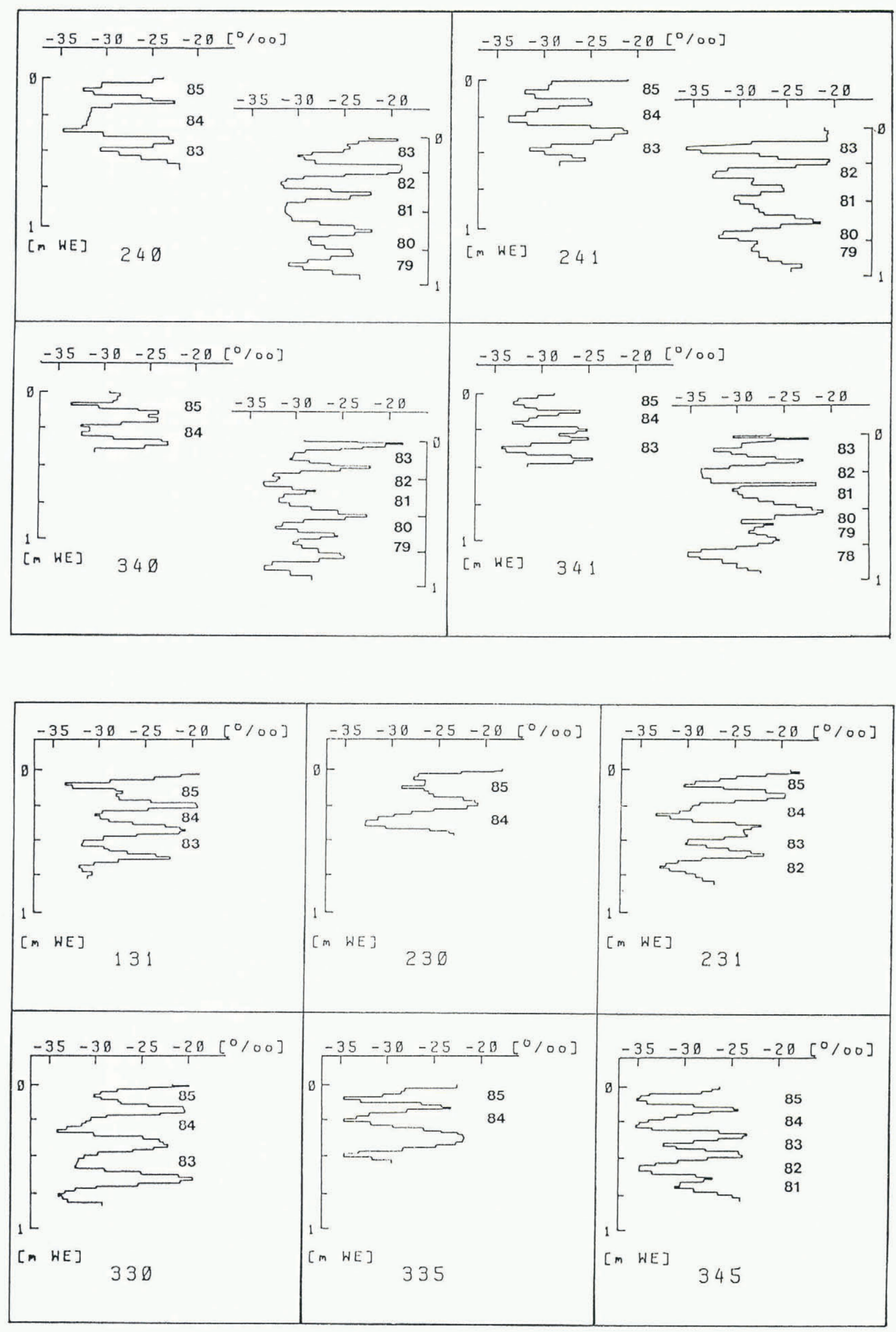

Fig. 2. Profiles of the ${ }^{18} \mathrm{O}$ content of snow-pits at measuring points of the 1983-84 and $1985-86$ field seasons (Fig. 1). The profiles of the snow-pits dug in 1984 are dislocated by the amount of the previous year's accumulation, so that corresponding years are displayed at the same level. 
indication of atmospheric water-vapour transport. However, at some points too few annual layers are available for a good interpretation of the spatial distribution of ${ }^{18} \mathrm{O}$ content (Fig. 3), and the lack of data from the Filchner III traverse is regrettable, since it could have provided the needed samples. A decrease in the ${ }^{18} \mathrm{O}$ content with increasing distance from the ice edge towards Möllereisstrom (cf. Fig. 1), and also westwards along the ice edge, is clearly recognizable in Figure 3. This may be explained by transport of air masses from the north-east. At points 131 and 230 , a high ${ }^{18} \mathrm{O}$ content was measured, but the snow-pits include only a few annual layers. Nevertheless, these points indicate a tongue-like pattern in this area of Ronne Ice Shelf.

\subsection{Accumulation rates}

The determination of the accumulation rates is based on the stratigraphy revealed by the annual variation in the ${ }^{18} \mathrm{O}$ content. Figure 4 shows the accumulation rates for 12 sites at which snow samples were taken during the 1983-84 and 1985-86 field seasons.

The great variation in accumulation from year to year is mainly due to the "roughness" of the snow surface, which has been formed by wind erosion. Obviously, drifting snow fills the hollows between sastrugi and smooths the surface. Thus alternating years of high and low snow accumulation can be found in a snow-pit (Fig. 5). The accumulation determined for the year 1983 at points 240,241 , and 341 differs by 10,12 , and $20 \%$ respectively. These differences can be regarded as a measure of the accuracy of the accumulation rates deduced from snow-pit studies. The variability of the layer thickness is also caused by changing amounts of precipitation and the changing intensity of wind erosion from year to year.

To determine accumulation rates which are not strongly influenced by the "roughness" of the snow surface, one has to analyse the annual layering over greater areas or to average it over several years. Snow-pits dug at adjacent sites in different years result in time series which cannot be linked without problems if they contain less than 5 years' accumulation.

In order to calculate the spatial distribution of the accumulation rates, only time series that cover the same period should be used. This would mean that only data from the 1984-85 and 1985-86 field seasons could be used in the present study. Unfortunately, some locations are then represented by only 2 or 3 years' accumulation. Therefore it was decided to use the average of all the values available for each location in order to determine the accumulation rates (Fig. 5). Points 230 and 330 show very high accumulation rates but, as the values for these points are based on only 2 or 3 annual layers, one has to consider them as preliminary. In general, Figure 5 displays a decrease in accumulation rate with increasing distance from the ice edge: it decreases from $21.3 \mathrm{~g} \mathrm{~cm}^{-2} \mathrm{a}^{-1}$ at point 140 (Filchner Station) to $13.7 \mathrm{~g} \mathrm{~cm}^{-2} \mathrm{a}^{-1}$ at point $341(270 \mathrm{~km}$

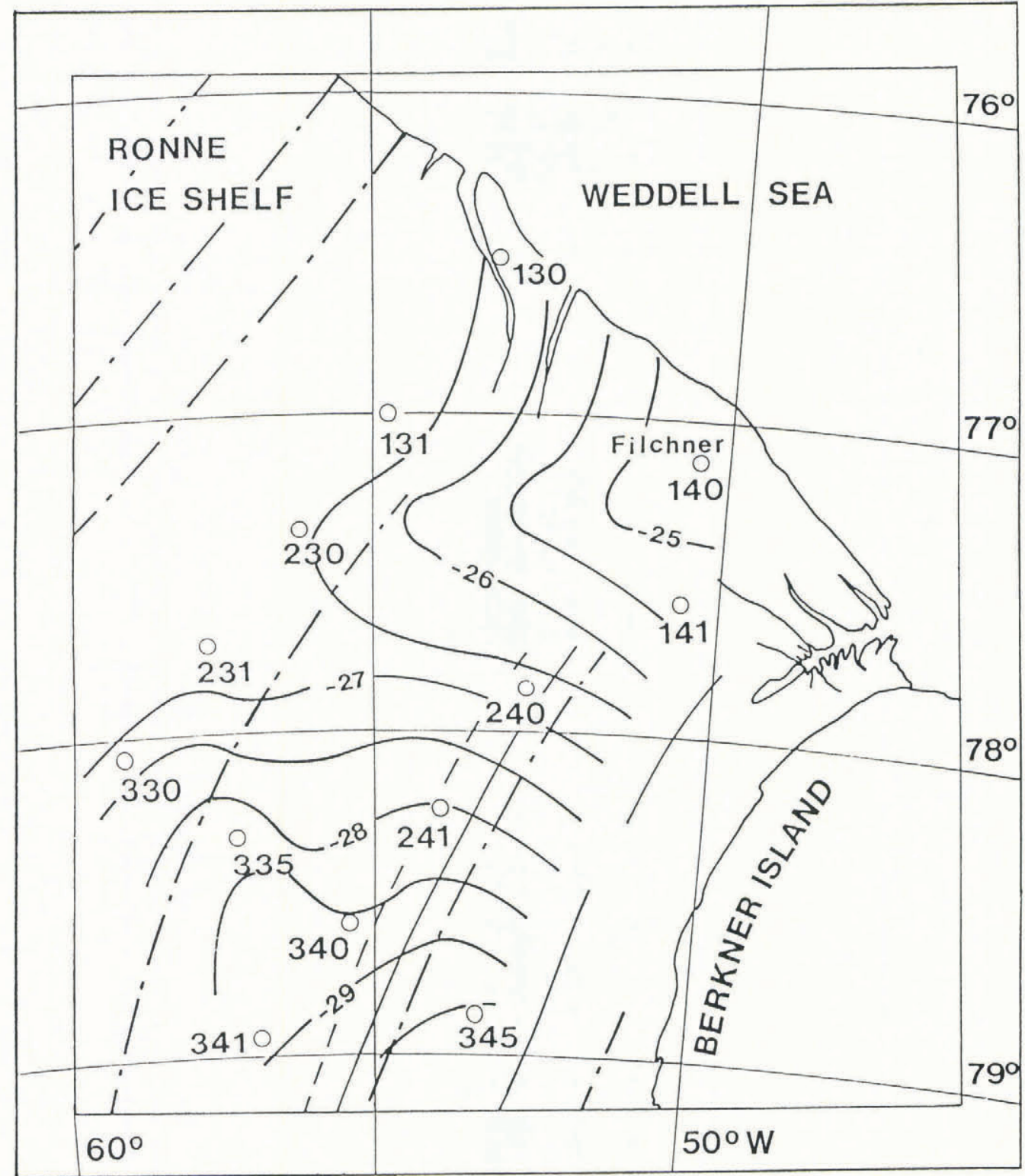

Fig. 3. Distribution of the ${ }^{18} \mathrm{O}$ content of near-surface snow layers in the eastern part of Ronne Ice Shelf. Isolines of the ${ }^{18} \mathrm{O}$ content are plotted at intervals of $0.5 \%$. 
Graf and others: Accumulation and ice-core studies on Filchner-Ronne Ice Shelf. Antarctica

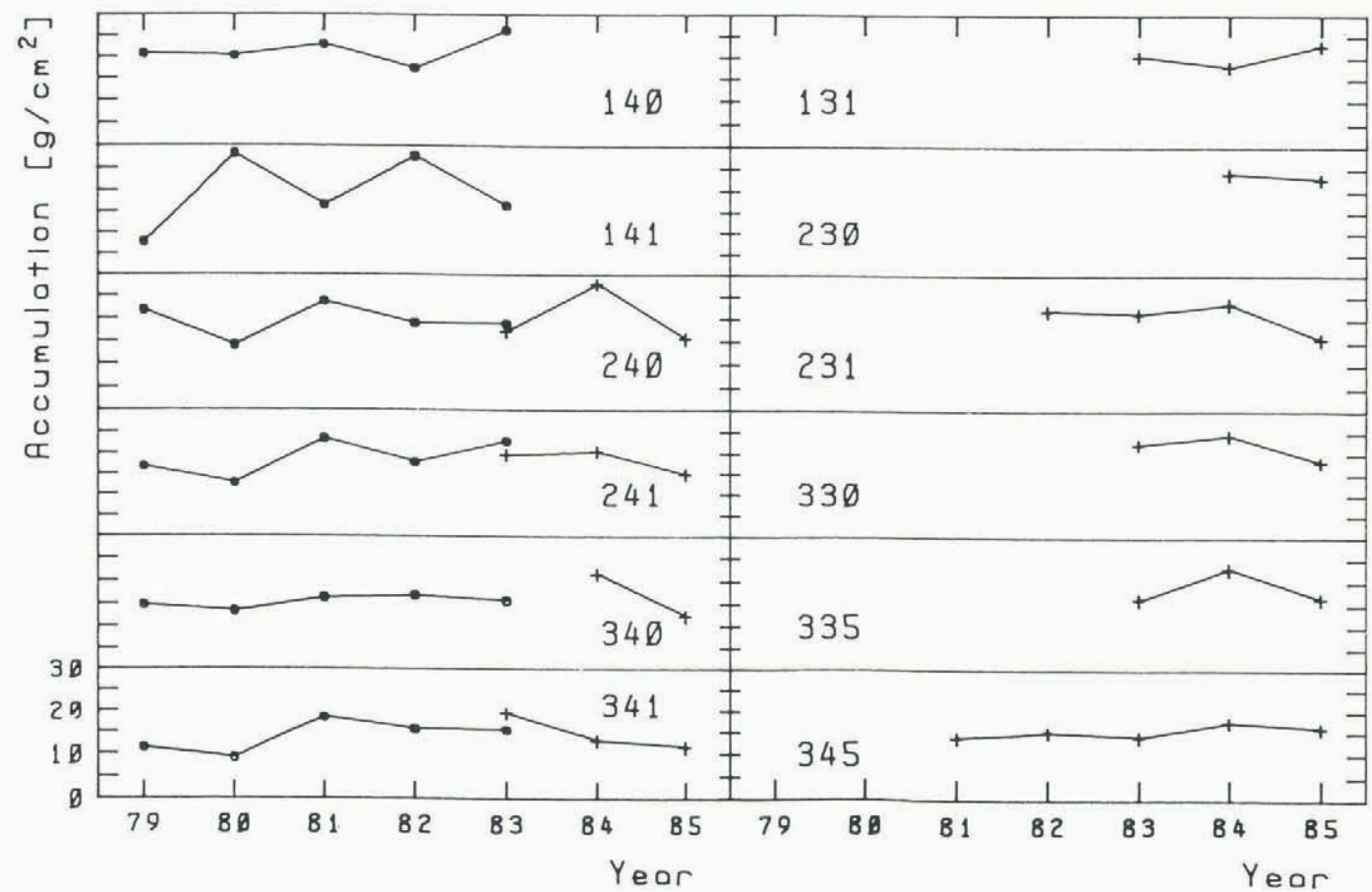

Fig. 4. Amount of annual accumulation at the measuring points of the Filchner I and Filchner II field programmes. (0) snow-pit 1984; (+) snow-pit 1986.

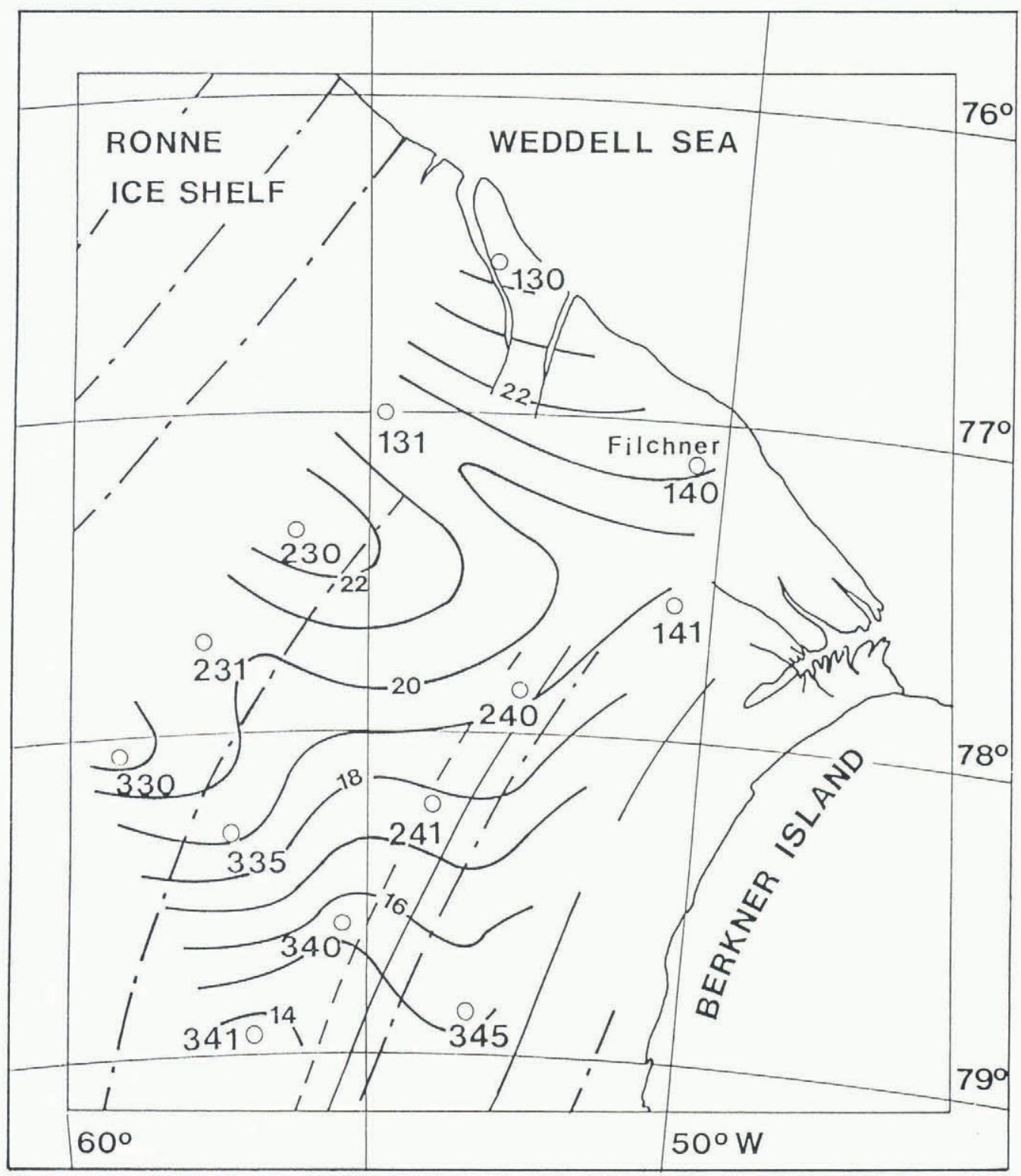

Fig. 5. Distribution of the accumulation rates in the eastern part of Ronne Ice Shelf. Isolines of accumulation are plotted at intervals of $1 \mathrm{~g} \mathrm{~cm}^{-2} \mathrm{a}^{-1}$. 

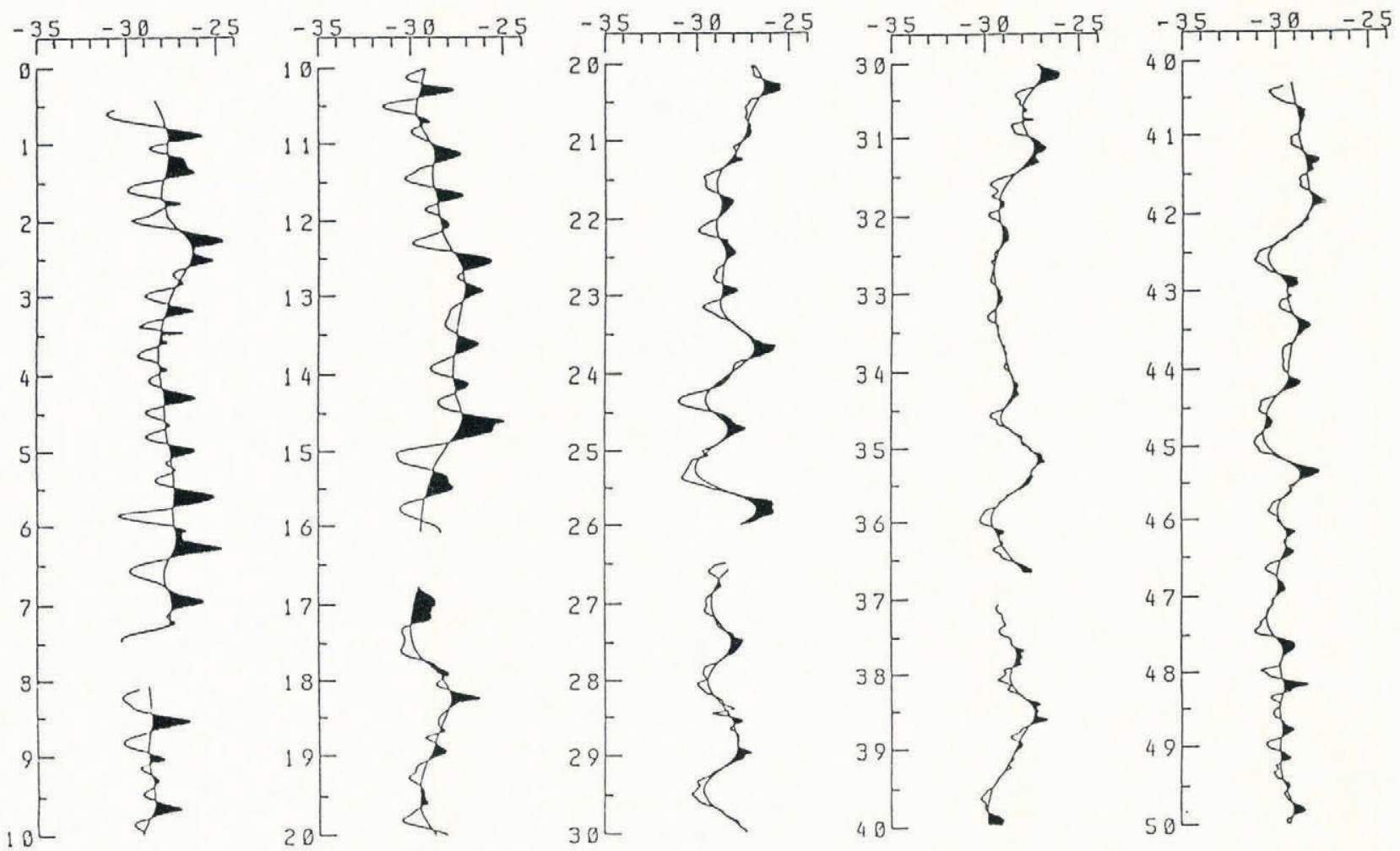

DEPTH $[\mathrm{m}]$
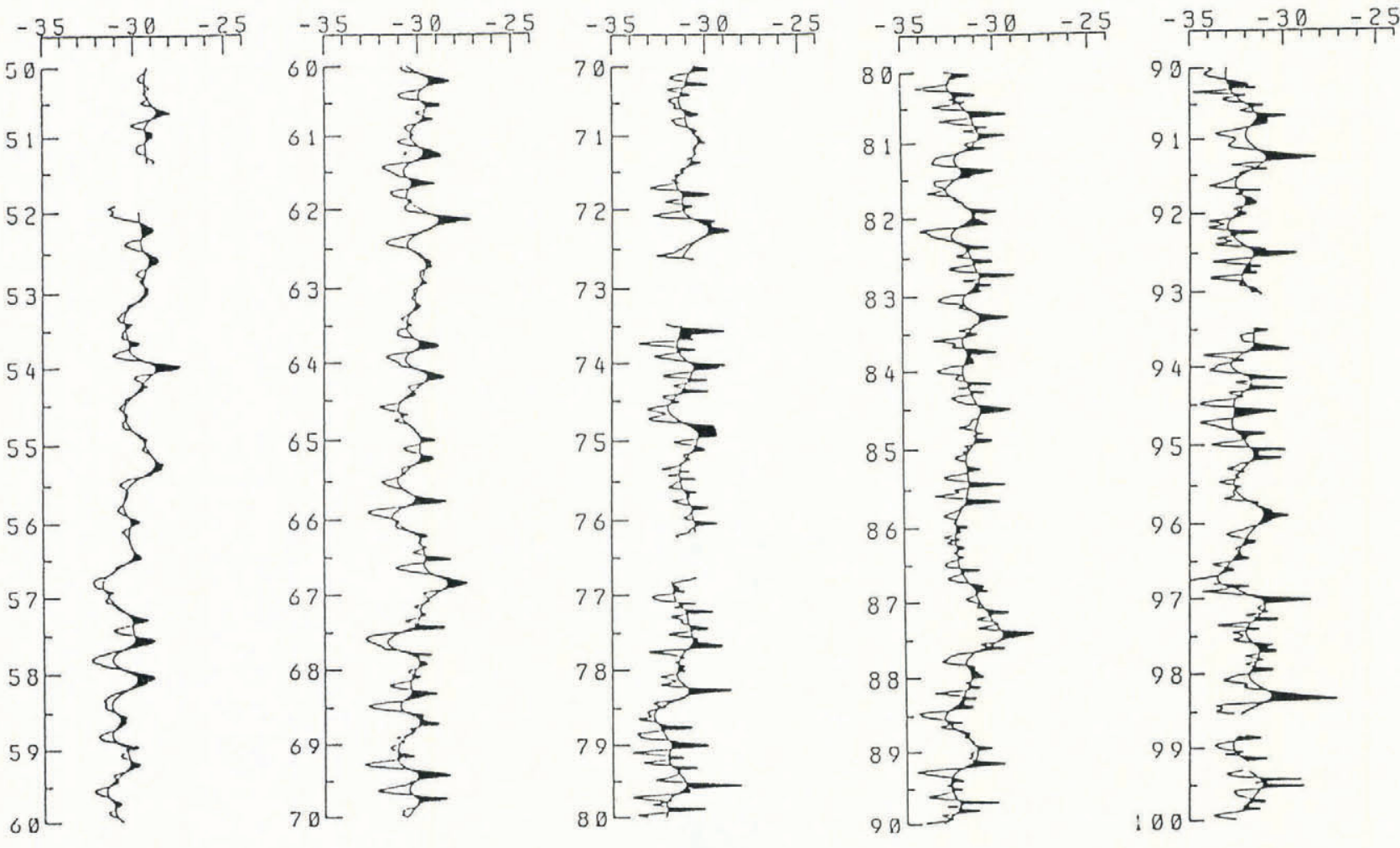

DEPTH $[\mathrm{m}]$

Fig. 6. ${ }^{18} \mathrm{O}$ profile of ice core T340, drilled in 1984 at point 340 on Ronne Ice Shelf (Fig. 1). Material originating from summer precipitation is dark-coloured. The base line represents the variation in the annual ${ }^{18} \mathrm{O}$ content.

south of the ice edge). The gradient is smaller $100 \mathrm{~km}$ to the west. There the accumulation rate decreases from $24 \mathrm{~g} \mathrm{~cm}^{-2} \mathrm{a}^{-1}$ at point 130 (the ice edge) to $21.3 \mathrm{~g} \mathrm{~cm}^{-2} \mathrm{a}^{-1}$ at point $330(250 \mathrm{~km}$ south of point 130$)$.

\section{ICE CORE T340}

The ${ }^{18} \mathrm{O}$ profile of ice core $\mathrm{T} 340$ (from 1 to $89 \mathrm{~m}$ depth) and a preliminary interpretation of variation in the accumulation rates on Ronne Ice Shelf have been published by Graf and others (1988). For the present study the bottom $11 \mathrm{~m}$ of the ice core have been analysed, again with the same high resolution of $1 \mathrm{~cm}$ intervals, corresponding to about 10 samples per annual layer. Seasonal variations, which are used for the stratigraphical dating, can clearly be detected also in this part of the ${ }^{18} \mathrm{O}$ profile (Fig. 6). 


\subsection{Dating of the core and layer thickness}

As in snow-pit studies, the decrease in ${ }^{18} \mathrm{O}$ content after a summer maximum was regarded as defining the boundary of an annual layer. Altogether 479 annual layers were found in the profile, although 80 are indicated only by small maxima or as shoulders on larger peaks. However, they are regarded as plausible if the layer thickness is taken into consideration. For ten depth sections not covered by ice cores ( $5 \mathrm{~m}$ altogether), 41 years were inserted in the time-scale, corresponding to the gaps and the layer thicknesses in the adjacent depth ranges. This approach yields an age of probably 520 years for the bottom layer, which was thus deposited in $c$. A.D. 1460. The thickness of the annual layers (in water equivalent, $\mathrm{cm}$ WE) was deduced from this chronology using the experimentally determined density-depth relation and is plotted in Figure 7a, together with the estimated accumulation rate (see section 4.2).

It is obvious that the reliability of the dating and the accuracy of detecting layer thicknesses depend on the quality of the isotopic profile. This, however, is influenced by (among other things) the deposition conditions, wind scouring, and sublimation processes during the transition of snow to ice. In addition, partial melting of the core during storage affected the first $89 \mathrm{~m}$ of the ${ }^{18} \mathrm{O}$ profile. Small variations in the ${ }^{18} \mathrm{O}$ content may be obliterated due to both sublimation and melting. Generally the reduction of the amplitudes by sublimation seems to have had less effect on ice core T340 than has been observed in Greenland ice cores (Johnsen 1977).

The annual variation in the ${ }^{18} \mathrm{O}$ content (Fig. $7 \mathrm{~b}$ ) may serve as a measure of the quality of the ${ }^{18} \mathrm{O}$ profile. The coincidence of ranges with low ${ }^{18} \mathrm{O}$ amplitudes and high layer thickness or accumulation rates respectively (Fig. 7) does not necessarily indicate that in this depth range the dating of the core fails on account of the weakness of the isotopic profile.

$$
\text { cm WE } \quad \delta^{18} 0-A m p l i t u d e \quad[\% 0]
$$$$
8^{18} 0 \text { Annual mean }[\% 0]
$$
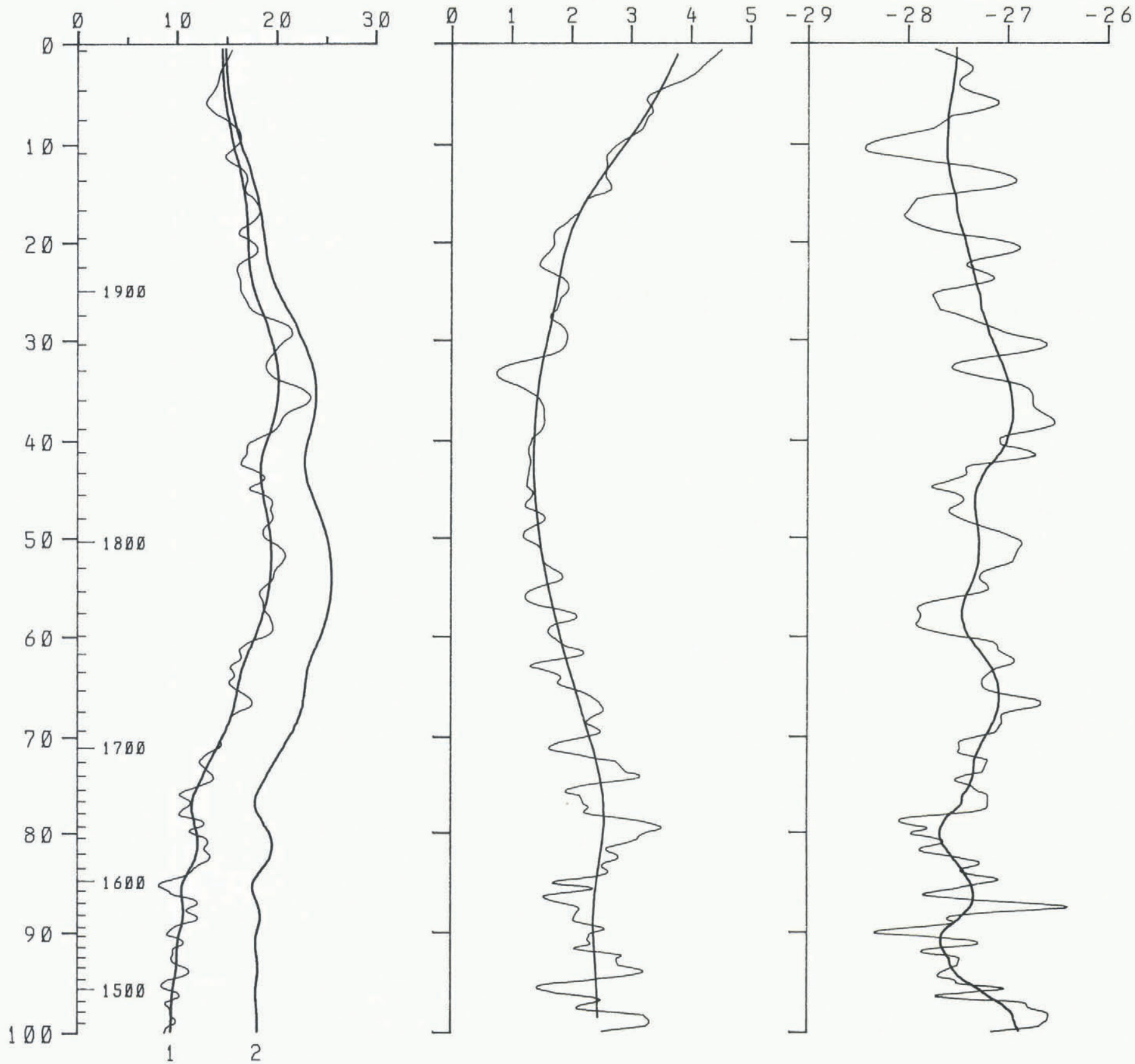

Depth Year

a)

b)

c)

Fig. 7. Ice core T340, drilled in 1984 on Ronne Ice Shelf: (a) (1) thickness of the annual layers, (2) estimated accumulation rates corrected for creep thinning, both versus depth and/or time of deposition in centimetres water equivalent; (b) annual amplitude of the ${ }^{18} \mathrm{O}$ content; (c) mean annual ${ }^{18} \mathrm{O}$ content after subtraction of the linear trend $\left(8^{18} \mathrm{O}=-27.3-0.049 z\right)$. All the curves have been smoothed by filtering techniques. 


\subsection{Estimate of the accumulation rate}

Accumulation rates can be inferred from the annual layer thicknesses, if the deformation of the layers since the time of deposition is taken into account, by using (for example) a flow model that describes the particle paths in the ice shelf.

A two-dimensional flow model (Thomas 1973) has already been adapted to give an indication of the particle paths in Ronne Ice Shelf (Graf and others 1988). It describes the trajectory of a layer deposited on the ice shelf, overburdened by new accumulation, densified as it reaches greater depths and modified in thickness as it moves seawards with the ice shelf. The model assumes a freely floating ice shelf, and that the vertical strain-rate is independent of depth. In this study the model was used to calculate: (i) the thinning of the annual layers since the time of deposition, and (ii) the distance along the flow line where the material forming the annual layers was originally deposited. For this purpose the strain-rate and the velocity of the ice along an ice flow line have to be known as input parameters. Because at present these parameters are not available for the area under investigation, values from three-dimensional modelling of Ronne Ice Shelf (Lange and MacAyeal 1986) are used.

The calculated thinning of each annual layer since the time of deposition was used to infer from the experimental layer thickness the accumulation rate of the corresponding year (Fig. 8a). On the other hand, the relation between the time and distance of deposition of the material was used to transform the time-dependent accumulation distribution into a local distribution up-stream of the drilling site (Fig. 8a). According to the calculations, the layers at the bottom of the ice core originate from precipitation deposited $248 \mathrm{~km}$ up-stream of the drilling site. This result is in good agreement with the estimate based on the decrease in the ${ }^{18} \mathrm{O}$ content of the core with depth, related to the surface gradient as derived from snow-pit studies (Graf and others 1988).

The accumulation pattern (Fig. 8a) shows a marked increase from 1981 back to 1890 and rather high accumulation rates back to 1750 , but lower accumulation rates in the seventeenth and sixteenth centuries. One should bear in mind that temporal and local variations have been allowed for. The local variation is known at two sites in the catchment area of the core, i.e. between Berkner Island and Henry Ice Rise, and $50 \mathrm{~km}$ up-stream of the drilling site (between points 340 and 341). In the latter area the snow-pit data show a slight decrease in the accumulation rate in the direction of Möllereisstrom (Figs 5 and 1). Thus the increase in the accumulation back to 1890, or between the drilling site and approximately $55 \mathrm{~km}$ up-stream (Fig. 8a), has to be interpreted as most probably a temporal variation. For the South Pole region Jouzel and others (1983) found a decrease of $15 \%$ in the mean accumulation rate, from $10 \mathrm{~g} \mathrm{~cm}^{-2} \mathrm{a}^{-1}$ in the period $1887-1930$ to $8.5 \mathrm{~g} \mathrm{~cm}^{-2} \mathrm{a}^{-1}$ in the period $1930-78$. On Ronne Ice Shelf the ice core at point 340 indicates a decrease of $14 \%$ for the same periods. For the area between Berkner Island and Henry Ice Rise the accumulation rates deduced from the ${ }^{18} \mathrm{O}$ profile agree well with the $18 \mathrm{~g} \mathrm{~cm}^{-2} \mathrm{a}^{-1}$ accumulation determined by the Ellsworth traverse in 1957 (Kojima 1964).

In a second run of the model, the particle paths were calculated, taking into account the additional input parameters of the derived accumulation data along the flow line and the density-depth relation at the drilling site(Fig. 8b).

a)

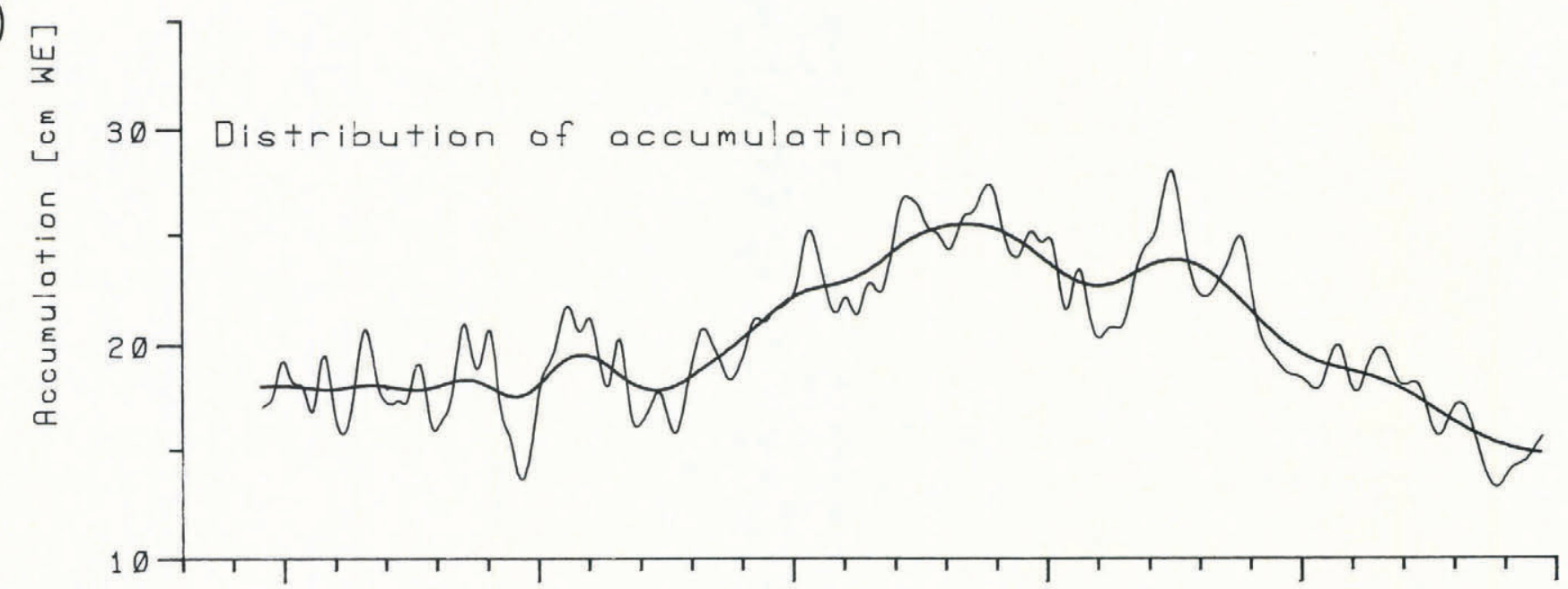

b)

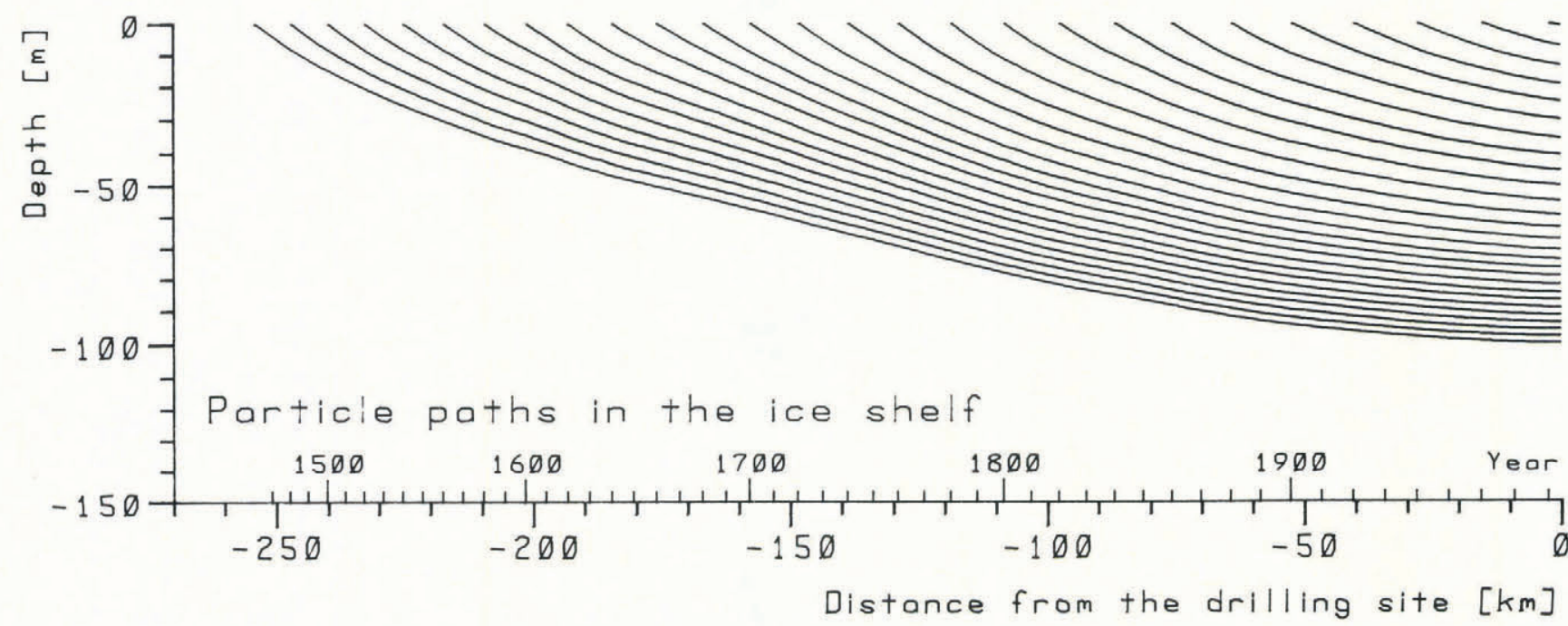

Fig. 8. Ice core $\mathrm{T} 340$, drilled in 1984 on Ronne Ice Shelf: (a) distribution of the accumulation rate up-stream of the drilling site, which fits the layer sequence found in the ice core; (b) particle paths to the bore hole. 
4.3 The decrease in ${ }^{18} \mathrm{O}$ content with depth

Samples recovered from a single core have various origins because of ice movement. The ${ }^{18} \mathrm{O}$ content of the core decreases with depth as a result of the isotopic continental effect, which fits the linear regression line

$$
\delta^{18} \mathrm{O}=-27.3-0.049 z
$$

where $z$ is depth in metres.

After subtraction of this trend, the variation in the $\delta^{18} \mathrm{O}$ content with time and/or depth is given in Figure $7 \mathrm{c}$. The curves show slight variations with time. Similar undulations are displayed by the ${ }^{2} \mathrm{H}$ profile at the South Pole (Jouzel and others 1983), which goes back to A.D. 1887. Further work will show whether a temperature variation in the past can be deduced from this profile.

\section{ACKNOWLEDGEMENTS}

The authors wish to express their gratitude to the Alfred-Wegener-Institut für Polar- und Meeresforschung, Bremerhaven, for logistic support, and to the Deutsche Forschungsgemeinschaft, Bonn, for financial support.

\section{REFERENCES}

Graf, W., O. Reinwarth, H. Moser, and W. Stichler. 1988. Investigation of the ${ }^{18} \mathrm{O}$ content of a $100 \mathrm{~m}$ ice core from the Ronne Ice Shelf, Antarctica. Ann. Glaciol., 10, 43-47.

Johnsen, S.J. 1977. Stable isotope homogenization of polar firn and ice. IAHS Publ. 118 (General Assembly of Grenoble 1975 - Isotopes and Impurities in Snow and Ice), 210-219.
Jouzel, J., L. Merlivat, J.R. Petit, and C. Lorius. 1983. Climatic information over the last century deduced from a detailed isotopic record in the South Pole snow. $J$. Geophys. Res., 88(C4), 2693-2703.

Kojima, K. 1964. Densification of snow in Antarctica. In Mellor, M., ed. Antarctic snow and ice studies. Washington, DC, American Geophysical Union, 157-218. (Antarct. Res. Ser., 2.)

Lange, M.A., and D.R. MacAyeal. 1986. Numerical models of the Filchner-Ronne Ice Shelf: an assessment of reinterpreted ice thickness distributions. J. Geophys. Res., 91(B10), 10457-10462.

Reinwarth, O. 1981. Glazialmeteorologische Arbeiten auf dem Filchner-Ronne-Schelfeis während der Standorterkundungsexpedition 1979/80. Polarforschung, 51(1), 61-75.

Reinwarth, O., W. Rauert, W. Stichler, and H. Moser. 1982. Preliminary investigations on accumulation at the Filchner/Ronne ice shelves and Atka Bay. Ann. Glaciol., 3, 274-278.

Reinwarth, O., M.A. Lange, and K.-H. Bässler. 1984. Programm und vorläufige Ergebnisse der glaziologischen Arbeiten auf dem Filchner-Schelfeis 1983/84. Ber. Polarforsch., 19, 37-52.

Reinwarth, O., W. Graf, W. Stichler, H. Moser, and H. Oerter. 1985. Investigations of the oxygen-18 content of samples from snow pits and ice cores from the Filchner-Ronne ice shelves and Ekström Ice Shelf. Ann. Glaciol., 7, 49-53.

Swithinbank, C., K. Brunk, and J. Sievers. 1987. Glaciological map of Filchner-Ronne-Schelfeis, 1:2000 000. Frankfurt am Main, Institut für Angewandte Geodäsie.

Thomas, R.H. 1973. The dynamics of the Brunt Ice Shelf, Coats Land, Antarctica. Br. Antarct. Surv. Sci. Rep., 79. 